\title{
INTEGRATION OF SKIING IN THE PROCESS OF TRAINING AND DEVELOPING FIGHTING SKILLS AND ABILITIES
}

\author{
Robert STĂNCIULESCU \\ "Nicolae Bălcescu” Land Forces Academy, Sibiu, Romania \\ rstanciulescu@armyacademy.ro \\ Fabiana BĂDĂLAN MARTINESCU \\ "Nicolae Bălcescu" Land Forces Academy, Sibiu, Romania \\ martinescu-fabiana@yahoo.com
}

\begin{abstract}
Thanks to the great benefits of using the skis in military actions, of which we can remember the great maneuverability and the possibility of using the element of surprise by organizing incursions and ambushes in difficult accessible areas covered by snow or ice in any weather condition, the development of the specific skills of this type of training is a priority objective in the training of the soldiers for the success of the fighting actions during winter time.
\end{abstract}

KEYWORDS: process, fighting, skiing, skills, technique

\section{Introduction}

Military physical education is one the foundation elements for the training of multi-skilled military personnel as a pillar of other training categories. It aims to develop basic motor skills, speed, expertise, endurance and strength at the highest level of performance. Therefore there occurs a process of training and improving the basic and applicative motor skills so as to provide the necessary physical performance necessary to fulfill the missions in accordance with the physical and psychic demands imposed by the modern war. In the training content of this discipline essential for maximizing performance, skiing takes a special place, because, by using specific means of movement that ensure the increase of the speed of movement and operation, many fighting actions carried out in mountainous areas, in wooded terrain, covered by snow or ice, day or night, have the assured success. The first military structures equipped with skis have brought great benefits in the battles carried out over time, therefore, taking into account that our country's relief is made up mostly of mountainous areas and this category of training occupies a special place in the training of our army.

2. Skiing in the World, Means of Travel, Fighting and Entertainment

With ancient origins lost in time immemorial, skiing has been a means for people to move into snow-covered and icecovered terrain, simply by making it easy to move for hunting, fighting, or entertainment. 
The millennial existence is confirmed by a series of data and objects discovered at different stages of the development of human society in the most diverse places on the globe, generating the idea that skiing is the oldest means of travel discovered by man. It appeared in the north to serve, as we previously mentioned, the human's interests, skiing not only served for walking on snow, but also on ice or mud, becoming increasingly used in various fields. If at first they of rackets were used, that represented a trellis (braiding of branches) that were used to walk on snow or mud in order to prevent sinking and ease the advancement, these materials have transformed into a sort of long or short bats, which, becoming shiny by friction or leather lining on the sole, ensured slipping or moving more easily onto the frozen or muddy grounds. Research in the field reveals that skiing must be at least 5000 years old (Matei, 1982). Many evidence shows that not only the northern nations of Europe used these livelihoods, but also the inhabitants of the Asian continent, like the Chinese or the Mongols benefited from materials with which they moved more easily. So they used some kind of flat footwear, a kind of leather-skinned rackets that helped them not to slip or sink in the snow or mud, or flat bats with which they could slide on ice or snow. All these findings concluded that skiing was born in Asia, in Central Asia more precisely, later spreading to America and northern Europe, initially in Norway and Finland, then in the Central European countries. The mountainous chains on the Romanian territory have always been a challenge for people and although life is not easy in these areas, they have always been a shelter for the inhabitants of our country. There is evidence that the inhabitants of the mountain areas have always sought and found solutions to move more easily on ice and snow covered lands to hunt, to defend themselves from enemies or simply for entertainment. Of course, the evidence shows that skiing as well as other means of traveling on snow, such as rackets to walk on snow, skates made of animal bones, or different types of sleighs appeared much later than in northern Europe, but they show that they have always been a concern for these people. Alexander Gwanin, in his paper The Chronicle of Sarmatian Europe, which appeared in 1578, refers to the fact that the inhabitants of the Carpathians are moving fast on snow on long and wide wooden skids, demonstrating the fact that they have been using this means of transport that helps them to transport light materials as well as to hunt (Bănciulescu, 1967). The evidence of the use of skis also exists in The Bihor Mountains or the Apuseni Mountains, the press of that time mentioning that the "moți" used simple skis and bonding built with great ingenuity from wood with which they crossed long distances during the winter periods. In the sports museums in our country (ClujNapoca, Bucharest or Braşov) there is clear evidence of practicing skiing in Romania. Snow skateboards, wooden skis or skates represent only a part of them. The skis are made of hardwood and have extremely resistant cow-leather bonding and the skates found in Sighişoara are made of wood, bone and metal. At the sports museum in Bucharest, there are bonds and skis that were used by the army or other population categories dating back to 1910-1920. The $19^{\text {th }}$ Century can be declared the beginning of winter sports in Romania, sports disciplines such as skiing, bobs, hockey or skates being part of the constant preoccupations of aristocracy in Romania. Heir Prince Carol was the patron of the Federation of Sports Societies in Romania founded in 1912 and included in his objectives the development of winter sports. The successor King Charles II was a famous skier, and there were many photographs of that time proving this (Kiritescu, 1964). A series of works devoted to this sport such as: skiing in 
pictures from 1929, 1934 Cross-country skiing, Ski technique, Skiing - method of learning, Mountain Technique for All, or Ski manual written by Prince Nicholas stand to confirm the interest for this category of training. After 1945, skiing becomes a sport available to all, being practiced by a large category of people offering unmatched satisfaction and proving its utility in more and more fields of activity.

\subsection{Skiing used as a Means of Fighting}

There is a great deal of evidence attesting to the importance of skiing in conducting combat actions and deciding on the outcome of the wars. Thus, in the $6^{\text {th }}$ century, the historic monk Jordanes shows in his work Actibusoue Gotharum Origin that the peoples of the north used to move on the long stretches of snow and that they went to battle using strange snow footwear that made their walking easier. Also in that period, the Byzantine historian Procopius in the work About Gothic Wars refers to fighters as Skrithifinci from slipping on light snow shoes (Matei, 1982). The first information on the use of skis by the military dates back to the 710s later on contributing too many internal wars or conquests. There is evidence showing that in 1200 a Swedish army led by King Sverre whose skies fighters wore lights successfully participated in the Battle of Cristiana, Oslo. The use of skis as a means of fighting in the Swedish campaigns in Russia, Poland or the 30-year war is also mentioned. In 1500, the skiers were common in the Russian army, where they always intervened successfully in the snowy areas, being equipped with highperformance skis and possessing well-made fighting equipment. Thus, in 1444, we are told about a military campaign against the Tatars attacking Reazanul and where thanks to the skier troops operating in the areas covered by the great snow were successful.
The Chronicle of Arhanghelgorod, a document from 1499 describes the battles carried out by a Russian skier army of the Prince Ivan Vasilievici in Inguria, and the Chronicle of Pskov describes the skier battles in Lithuania in 1535 (Bănciulescu, 1967). In 1670 , in the war between Denmark and Sweden, a commando of sixteen Danish skier fighters destroyed a unit of 200 Swedish fighters. Norway was aware of the value of skiing in the training of its army and in 1774 it organized the first ski regiment and opened two military ski schools. Immediately, Sweden takes steps to organize the skiing training of several military units. Another country where skiing did its job properly, in terms of means of fighting, was Finland. The famous White Patrols, Finnish elite units on skis were able to move $80-100 \mathrm{~km}$ in only 10 hours and thanks to this exceptional ability to move, they have achieved remarkable successes in battles. During the two world wars skiing was used especially in different battles and commando missions. In World War II, an elite Norwegian team consisting of 6 ski fighters managed to fulfill an almost impossible mission. Because of exceptional training, they have infiltrated an area almost inaccessible, in the Telemarc Mountains, in an ice and snow covered area, in a rocky area where only birds had access, through cold, dark and fog, they managed to blow up a large water plant, extremely useful to Nazi Germany. It was a great success, especially because they left safe, becoming real heroes for their country and their people. Nowadays, in all the countries that benefit from alpine fields, there are military units equipped with skiing and other individual winter means of travel and their training is a main objective due to the extremely important benefits they offer in carrying out the fighting actions.

\subsection{The Contribution of Skiing to} the Training of the Romanian Army

In 1916, the Romanian army was in war. The Romanian troops were fighting hard to cope with the rigors imposed by the 
conditions of that time. Having to defend the passage of the Carpathians, due to poor training, inappropriate equipment and the fact that they did not know the principles of fighting in the mountains, which involved being in control of the chines and the flanks, the Romanian army lost the battle (Dan, 2012). This made the army leaders at that time think and it decided to change the way to organize battles in the mountains. Specialized warriors were needed, equipped with the appropriate equipment to be able to operate easily and with great ability to move and act in hard-to-reach areas. The first organizational form that would lay the foundations of the new mountain hunting troops was the ski school in Bucharest founded in 1916 in the 4 Rosiori Regiment, whose staff were about 1,000 places. In November 1916, the Ski School was transformed into the Mountain Winter Corps, organized on three battalions of three companies with a total of 2,000 fighters, designed to carry out missions for safety, connection and reconnaissance, but which also functioned as a tactical unit especially in passages from the Carpathian Mountains. In December, it turns into the Batalion de Vanatori de Munte (Mountain Troops Battalion), which took part in the battle of Oituz to conquer some of the greatest heights, the most important being Cosna and Ciresoaia. In 1917 and 1919 ski courses are organized for Mountain Troops in Postăvaru and Tihuţa. In the years 1919 and 1921, mountain troop units have been set up, with priority being given to preparing ski missions. Between the two world wars, the military leadership of our country, conscious of the invaluable value of the mountain troops specializing in the fight on skis, intensified the establishment of specific units in 1939 there were 4 brigades that totalized 16 mountain troop battalions, 3 mountain hunting divisions and 6 divisions of mountain guns. In the campaigns of the Second World War mountain troops acted in a giant geographic space proving their qualities of fearless fighters, well-trained soldiers to efforts and indigence, disciplined and ready for the ultimate effort. Mountain Troops are now constituted in supple combat and maneuvering units, in accordance with the requirements of the current theaters of operations capable of firm hit backs in any situation and the training on skis is being carried out for the purpose of learning the technical procedures of travelling on snow, mountains, woods, with various inclinations, to subsequently perform fighting on skis, safely and efficiently in the tactical field. The objectives of the ski instruction are the following: learning, enhancing and perfecting the movements of the front on skis, the procedures for controlling the speed of sliding on the slope, the procedures for skiing, the procedures for bypassing and crossing the various obstacles on skis, as well as the training of the soldiers for carrying out the military action techniques on skis. The technical processes to be learned in this discipline are: two-step alternating walking, two steps and simultaneous pushing, falling off and standing up from the fall, climbing and moving in inclined terrain, slowing down, bypassing, direct and sidelong descent, crossing the bumps and obstacles in the field, stopping and bypassing by successive steps, Christiania turn towards the valley by separating the legs, detachment, or by rotation. We add to all this the important role that it has in physical conditioning and strengthening of health by using the natural factors for conditioning and adapting the body to the natural conditions in which the activity is being carried out, strengthening once again the idea that a healthy mind needs a healthy body (Stănciulescu, 2017).

\section{Conclusions}

Physical training with special implications for both physical and psychic health, skiing is practiced by all categories 
of people from children to retirees, offering unmatched satisfactions and undoubtedly constantly demonstrating that it is a temple in which courage, physical and spiritual vigor engage in the most harmonious way with useful, beautiful and good will. At the same time, skiing contributes fully to the training of the soldiers to carry out fighting actions in the mountainous lands covered by snow or ice in any time or weather conditions, day and night, with clear objectives of defending the national mountain range, ready whenever to demonstrate professionalism, morality, dedication, and spirit of sacrifice.

\section{REFERENCES}

Bănciulescu, V. (1967). Sport şi legendă, Bucureşti: C.N.E.F.S.

Dan, S. (2012). Istoricul trupelor de vânători de munte în România, available at: http://newsbv.ro/2012/11/01/istoricul-trupelor-vanatori-munte-romania/, accessed on: 12.01.2018

Matei, I. (1982). Marea aventură a schiului, Bucureşti: Albatros.

Kiritescu, C. (1964). Palestrica, Bucureşti: U.C.F.S.

Stănciulescu. R. (2017). Didactica activităţilor fizice cu caracter aplicativ-militar, Sibiu: Academia Forţelor Terestre „Nicolae Bălcescu”. 